\title{
RESISTÊNCIA À TRAÇÃO DE COMPÓSITOS DE MATRIZ POLIÉSTER REFORÇADOS COM TECIDO PURO DE RAMI ${ }^{\star}$
}

\author{
Caroline Gomes de Oliveira ${ }^{1}$ \\ Janine Feitosa de Deus ${ }^{2}$ \\ Ygor de Moraes Macabu ${ }^{1}$ \\ Marcus Vinícius Fonseca Ferreira ${ }^{1}$ \\ Lucas de Almeida Pontes ${ }^{1}$ \\ Djalma Souza ${ }^{3}$ \\ Frederico Muylaert Margem ${ }^{4}$ \\ Sérgio Neves Monteiro
}

\section{Resumo}

Nas últimas décadas, as fibras naturais têm sido investigadas como uma alternativa para a utilização de fibras sintéticas, como material de reforço, tais como fibras de vidro. Algumas vantagens das fibras naturais são a menor densidade, biodegradabilidade e o fato de virem de fontes renováveis. Com o intuito de melhorar ainda mais as propriedades de compósitos de fibras naturais, investiga-se o desempenho de compósitos reforçados com tecidos de fibras naturais, uma vez que estes proporcionam um reforço multidirecional e permite a introdução de uma maior fração de volume de tecido. Neste trabalho, investigou-se a resistência à tração dos compósitos com matriz de poliéster reforçados com diferentes frações de volume de tecido de rami, que é uma das mais lignocelulósicas mais resistentes. Os espécimes foram testados em uma máquina universal de ensaios Instron. Os resultados mostraram um aumento na resistência à tração com o aumento da fração de volume de tecido.

Palavras-chave: Compósitos; Tecido de Rami; Fibras naturais; Poliéster

\section{TENSILE BEHAVIOR OF POLYESTER MATRIX COMPOSITES REINFORCED WITH PURE RAMIE FABRIC}

\section{Abstract}

In the last decades, the natural fibers have been investigated as an alternative to the use of synthetic fibers as reinforcement material, such as glass fiber. Some advantages of the natural fibers are the lower density, renewability and biodegradability. Aiming to further improve the properties of natural fibers composites, it is investigated the performance of composites reinforced with natural fibers fabrics, since they provide multidirectional reinforcement and enables the introduction of a larger fabric volume fraction. In this work, it was investigated the tensile strength of the polyester matrix composites reinforced with different volume fractions of Ramie tissue, which is one of the strongest lignocellullosic fibers. The specimens were tested in an Instron universal testing machine. The results revealed a increase in the tensile strength with the increase of tissue volume fraction.

Keywords: Composites; Ramie fabric; Natural fibers; Polyester

1 Metallurgical and Materials Engineering, undergraduation student, Laboratory of Advanced Materials, State University of the Northern Rio de Janeiro Darcy Ribeiro, Campos dos Goytacazes, RJ - Brazil

2 Metallurgical and Materials Engineering, M. Sc., Doctor Student, Laboratory of Advanced Materials, State University of the Northern Rio de Janeiro Darcy Ribeiro, Campos dos Goytacazes, RJ - Brazil

3 Metallurgical and Materials Engineering, D. Sc., Associated Professor, Laboratory of Advanced Materials, State University of the Northern Rio de Janeiro Darcy Ribeiro, Campos dos Goytacazes, RJ - Brazil.

4 Metallurgical and Materials Engineering, D. Sc., Assistant Professor, Center of Science and Engineering, Redentor University, Itaperuna, RJ - Brazil.

5 PhD Metallurgical and Materials Engineering, PhD, Main Professor, Laboratory of Materials and Metallurgy, Military Institute of Technology, Rio de Janeiro, RJ - Brazil. 


\section{INTRODUCTION}

Conflicts regarding the use of non-renewable forms of energy are increasing the interest in the investigation of new alternatives that meet the environmental demands $[1,2]$. In the recent decades, the natural fibers have been studied as an environmentally friendly alternative to the use of synthetic fibers, due to its lower cost, lower density, lower abrasion to the equipment, biodegradability and renewability $[3,4]$. Besides that, the natural fibers also contribute to balance the emission of $\mathrm{CO}_{2}$, because the plants absorb this component during their cultivation. It is also valuable to remember that these fibers come from renewable sources, in addition to being abundant and have a relevant set of mechanical properties [5].

The engineering application of natural fibers extracted from cellulose-containing vegetables, also recognized as lignocellulosic fibers, is currently considered an environmentally alternative to replace synthetic fibers $[6,7]$. It was found that due to a significant change in the quality of natural fibers, they are remarkably emerging as reinforcing materials in composites that hold an enormous potential for achieving sustainability [8]. One of the most resistant lignocellulosic fibers is Ramie, which can reach a tensile strength higher than $1000 \mathrm{MPa}$. Moreover, polyester composites with the thinner ramie fibers reached $280 \mathrm{MPa}$ for $30 \%$ volume fraction of fiber in flexural tests [9].

In order to further improve the performance of the natural fiber composites, it is investigated the performance of composites reinforced with Ramie fabrics, instead of its aligned fibers. The fabric reinforces the matrix in more than one direction simultaneously and also enables the introduction of a higher fraction of reinforced material. This new configuration regarding the use of Ramie fabric has already being tested for bulletproof panels and jackets [10]. Reported results have shown that polyester matrix composites reinforced with Ramie fabric have a potential for industry application. For this reason, the present work evaluated the tensile behavior of composite reinforced with Ramie fabric.

\section{EXPERIMENTAL PROCEDURE}

The fabric used for this work was obtained by the Chinese company Rose Natural Healthy Items Wholesale. Its density was measured by the Principle of Archimedes and the value obtained is $245 \mathrm{~g} / \mathrm{m}_{2}$. After that, the fabric was cut in the mold form and the specimens with different fabric volume fractions were individually confectioned by incorporating 1, 2 and 3 fabric layers into the composite. For this, an enough quantity of polyester resin was poured into the mold and then the fabric layers were placed onto it alternately with new resin layers. The specimens were cured for 24 hours and after tested in an model 5582 universal Instron machine at an acclimatized 25 $\mathrm{C}$ and a strain rate of $3.10^{-3} \mathrm{~s}^{-1}$. 


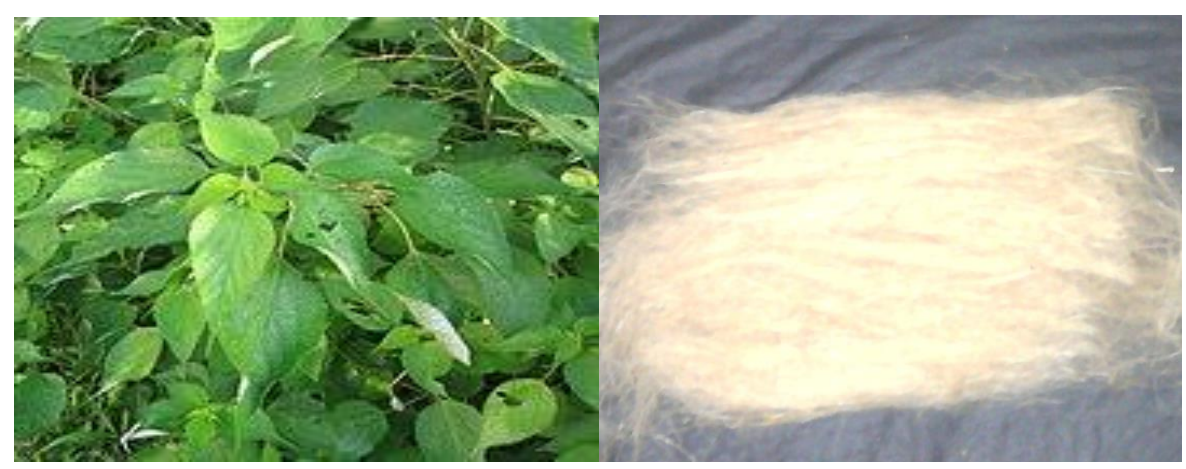

Figura 1. The ramie fiber (a) and a bundle of ramie fibers (b).

\section{RESULTS AND DISCUSSION}

The typical load vs elongation curves for the pure polyester ( $0 \%$ fabric) and different composites are exemplified in Fig.2. These curves were recorded directly from the Instron digital acquisition that program. They revealed that the ramie fabric reinforced polyester composites present limited plastic deformation. After a straight elastic line, a sudden fracture occurs, indicating a brittle behavior for both the pure polyester and the ramie fabric composites tensile specimens.

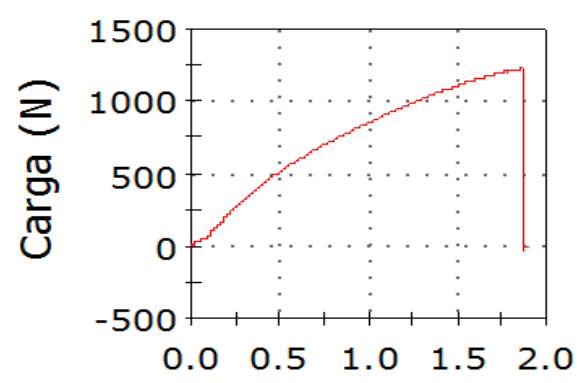

Extensão de tracção $(\mathrm{mn}$

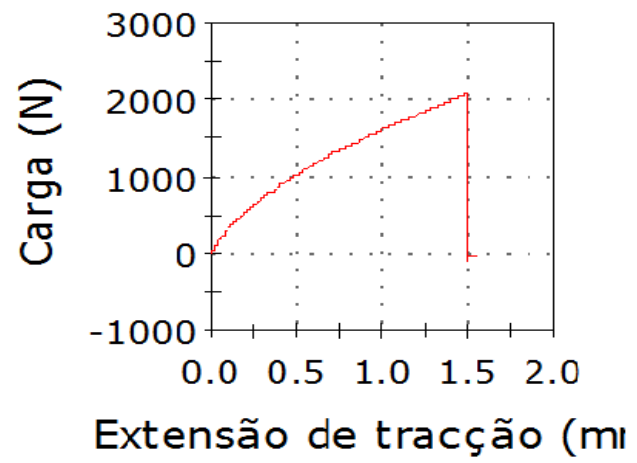

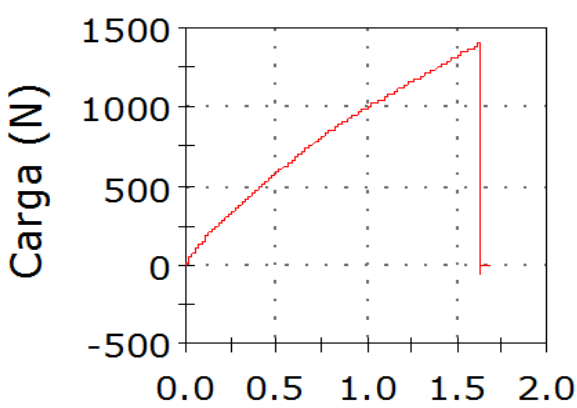

Extensão de tracção (mr

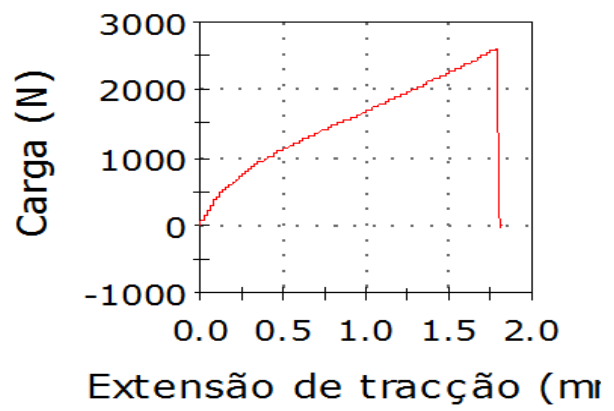

Figure 2. Typical load vs elongation curves for polyester composites reinforced with different volume fractions of ramie fabrics.

Figure 3 illustrates the macro aspect of tensile ruptured specimens corresponding to the different volume fraction of ramie fabric. In this figure, the fracture of all specimens tends to be transversal to the tensile axis. No macroscopic evidence of ramie fabric participation could be detected. This apparently indicates that the fracture mechanism for the ramie fabric reinforced composites was mainly associated with the propagation of transversal cracks through the brittle polyester matrix. 

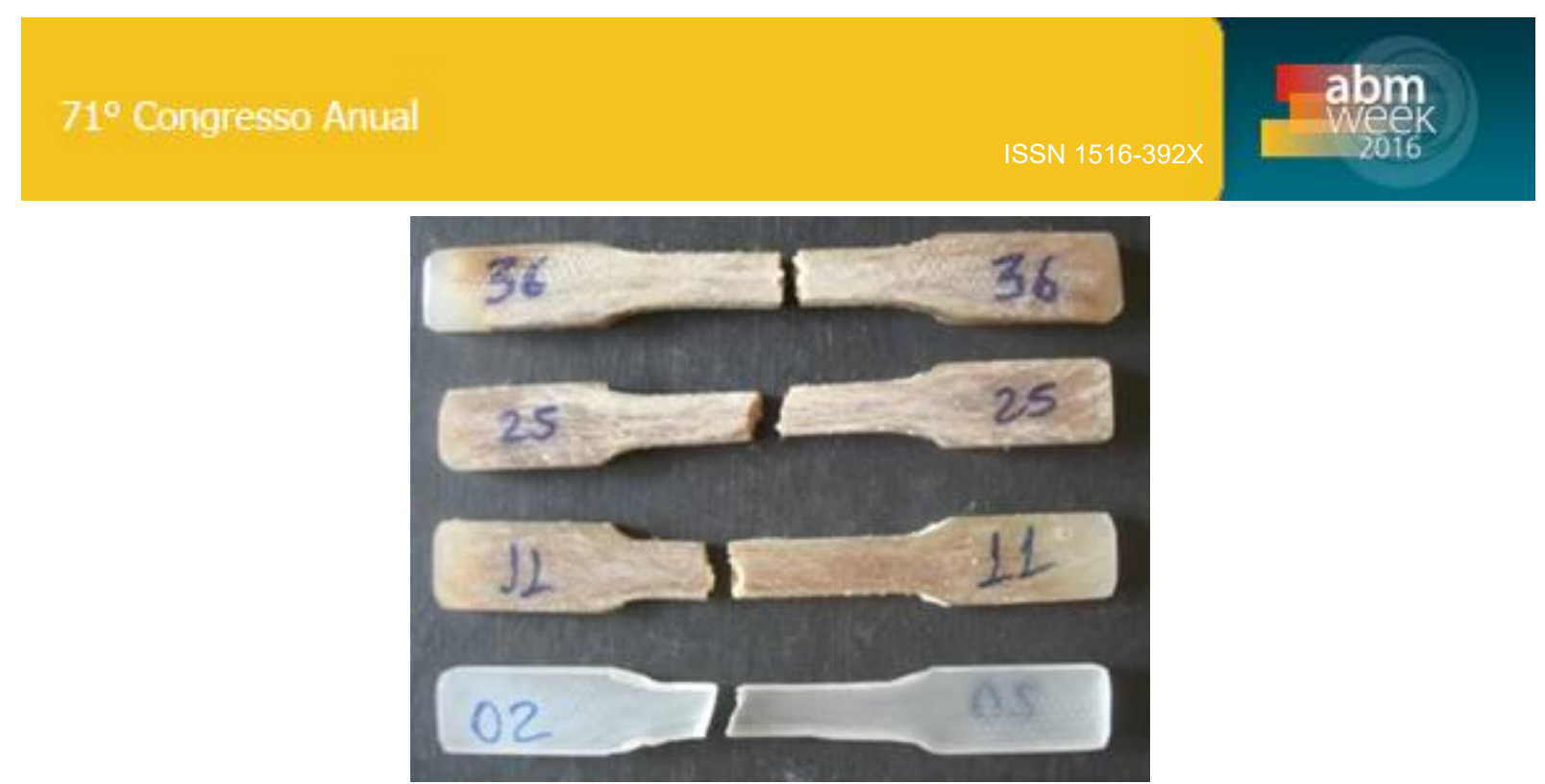

Figure 3. Full view of typical tensile ruptured specimens for each investigated volume fraction of thinner ramie reinforced epoxy composites.

Figure 4 displays the graphical results for the variation of both the tensile strength and the elastic modulus with the volume fraction of ramie fabrics. In this figure it can be noticed that both the strength, Fig. 4(a), and the elastic modulus, Fig. 4(b), vary within the error bars in an almost linear way. This characterizes a strong reinforcement effect of the ramie fabric to the polyester matrix. In fact, this reinforcement represents an increase of three times in the strength and four times in the elastic modulus for the 3 layers fabric composite in comparison to the pure polyester. Although not as expressive, the total strain also increases for the 2 and 3 layers. The reason for this reinforcement will further discussed in terms of the fracture behavior of the composite.
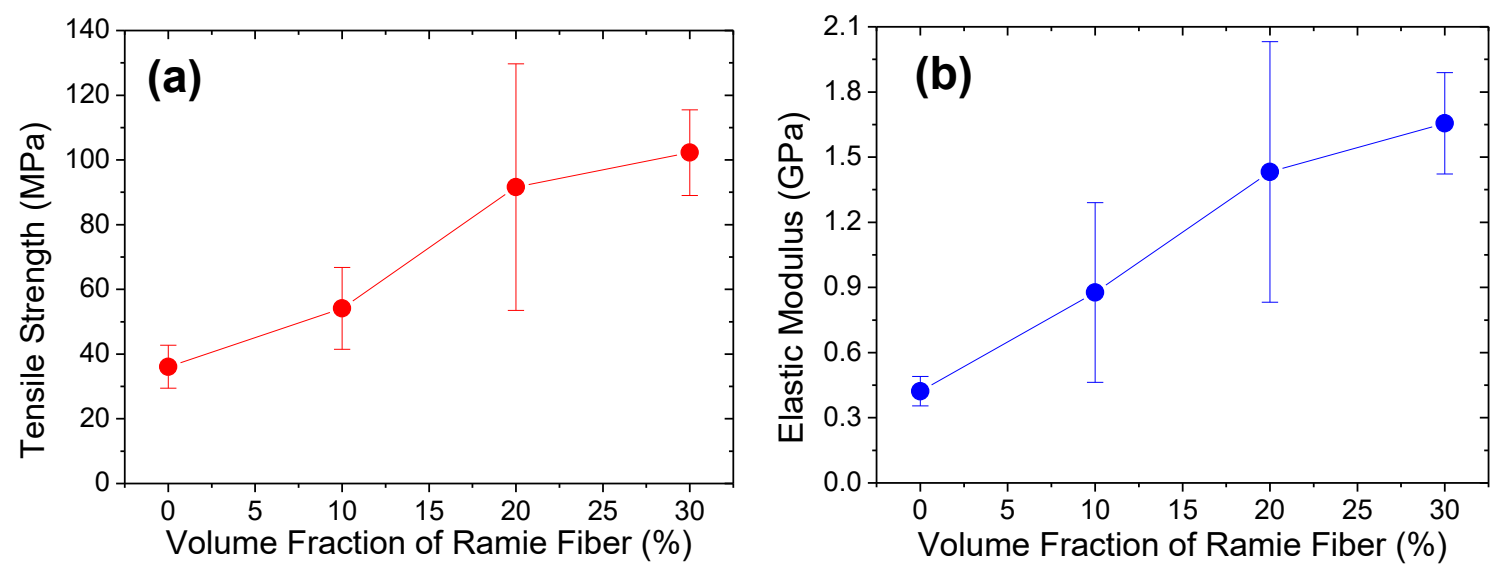

Figure 4. Variation of the tensile strength (a) and elastic modulus (b) with the volume fraction of thinner ramie fibers in poliester composites.

\section{CONCLUSIONS}

- Tensile tested polyester composites reinforced ramie fabric display a significant increase in both the strength and the elastic modulus with the fabric volume fraction.

- Up to 3 layers of ramie fabric volume fraction, the tensile strength increases three times while the elastic modulus increases four times in comparison with corresponding values of pure polyester. The total strain also shows a moderate increase above 1 layer of volume fraction. 


\section{Acknowledgements}

The authors thank the support to this investigation by the Brazilian agencies: CNPq, CAPES, FAPERJ.

\section{REFERÊNCIAS}

1 S.N. Monteiro, F.P.D. Lopes, A.S. Ferreira, D.C.O. Nascimento, "Natural fiber polymer matrix composites: cheaper, tougher and environmentally friendly", JOM, 61 (2009) 1722.

2 A.K. Mohanty, M. Misra, L.T. Drzal, "Sustainable biocomposites from renewable resources: opportunities and challenges in the green material world", J. Polym. Environ., v.10, (2002) 19-26.

3 P, Wambua, I. Ivens, I. Verpoest, "Natural fibers: can they replace glass and fibre reinforced plastics?", Composites Science and Technology, v.63, (2003) 1259-1264.

4 A.N. Netravali, S. Chabba, "Composites get greener", Material Today, v.6, p. 22-29, 2003.

5 J. Crocker, "Natural materials innovative natural composites", Materials Technology, n.2-3, (2008)174-178.

6 Nabi Sahed, D. and Jog, J.P. Natural fiber polymer composites: a review, Advances in Polymer Technol., 18 (1999), 221-274.

7 Mohanty, A.K., Misra M. and Hinrichsen, G. Biofibers, biodegradable polymers and biocomposites: an overview, Macromolecular Mat. And Engineering, 276/277 (2000), 1 24.

8 S. Kalia, B.S. Kaith, I. Kaur, "Pretreatments of natural fibers and their application as reinforcing materials in polymer composites - A review", Polym. Eng. Sci, 49 (7) (2009) $1253-1272$.

9 S.N. Monteiro, K.G. Satyanarayana, F.P.D. Lopes, "High strength natural fibers for improved polymer matrix composites”, Mater. Sci. Forum, 638-642 (2010) 961-966.

10 Milanezi TL. Comportamento Balístico da Fibra de Rami em Blindagem Multicamadas [Dissertação]. Rio de Janeiro: Instituto Militar de Engenharia; 2015. 